\title{
Laterite Rock Modified Asphalt Concrete Mix Design Properties and Swell Behaviour under Soaked Conditions for Rural Roads
}

\author{
Tom West, Jenbarimiema, Nyebuchi, Daniel Azeruibe* \\ Department of Civil Engineering, Rivers State University, Nkpolu Oroworukwo. Port Harcourt, Rivers State, \\ Nigeria
}

*Corresponding Author: Nyebuchi, Daniel Azeruibe, Department of Civil Engineering, Rivers State University of Science and Technology, Port Harcourt, Rivers State, Nigeria

\begin{abstract}
The consequential cost and the required labor associated in obtaining construction materials combined with other factors such as adverse environmental conditions and poor construction and maintenance practices have made pertinent the need for research into possible replacements for coarse aggregates in asphalt concrete. Different researches have shown that the inclusion of mineral fillers in hotmix asphalt concrete could increase its properties considerably. It is on this basis that this research attempts to investigate the effect of Portland cement on the retained strength and swelling index of laterite rock asphalt concrete, which will serve as basis for the use of laterite rock in pavement construction. An experimental approach was adopted to achieve this goal using the Marshal Mix design method to prepare representative samples. Stability and flow were obtained using the Marshal apparatus, while the retained stability index and swelling index of the samples for both un-soaked and soaked conditions were calculated. The results show that properties such as stability, density, flow, and voids, obtained from the modified laterite rock HMA concrete was better than that of the conventional (unmodified) laterite rock HMA concrete due to the addition of ordinary Portland cement. However, 8\% OPC content by weight of aggregates is the threshold content to attain optimum values of stability while there is considerable reduction in swell corresponding to less exposure to water.
\end{abstract}

Keywords: Portland Cement Concrete, Asphalt Concrete, Stability, Density, Modified, Swell Index and Mix Design Properties.

\section{INTRODUCTION}

Reducing the cost of construction of asphalt concrete pavement while maintaining the necessary properties is one of the concerns of the highway engineer. Aggregates occupy $95 \%$ of the volume of asphalt concrete and affect its properties, mix proportion, and economy to a large extent. Thus, any effort of reducing the cost of aggregate will have a direct impact on reducing the cost of construction (Ephraim, Adoga, \& Rowland-Lato, 2016). This has given rise to the need to investigate various nonconventional aggregateswhich can be sourced locally and are cheaper to make satisfactory dataavailable to serve as alternatives,

There is abundance of Lateritic materials all over the world, especially in tropical regions with high characteristic rainfall and persistently high temperatures. The typical regions of occurrence of laterite include India, Burma, Indonesia, Malaysia, Australia, Africa, and interior parts of South America (Raju Krishna 2006). An extensive area of Nigeria is covered with laterite materials in various weathered states, ranging from clay laterite, sandy laterite to rock laterite (Ephraim, Adoga, \& Rowland-Lato, 2016)

Lateritic soils contribute to the general economy of thetropical and subtropical regions where they are in abundance because, they are widely utilized in civil engineering worksas construction materials for roads, houses, landfill for foundations, embankment dams, etc. As a road constructionmaterial, they form the sub-grade of most tropical road, andcan also be used as sub-base and base courses for roads thatcarry light traffic. (Aginam, Nwakaire, \& Nwajuaku, 2015).

The increasing cost of construction of asphalt pavements as a result of increasing cost of aggregate has led to highway pavements being left unattended to or half complete causing unnecessary delay in traffic flow, distortion of pavement aesthetics, and most significantly, loss of lives and property 
(Afolayan \& Abidoye, 2017). As a result, it is important to discover and investigate alternative aggregates which can be sourced locally and are cheaper in cost while satisfying the necessary requirements (which is the attempt of this study), to overcome the challenges mentioned above.

However, there is dearth of reliable data on the effect of laterite rock as coarse aggregate in the surface course of asphalt concrete pavements especially within the Nigerian terrain, considering the fact that a significant number of researches conducted have dwelled on the use of laterite as base or sub-base material. As a result, it is difficult to adequately quantify the effect of using laterite rock as coarse aggregate on asphalt concrete pavements.

Researches have shown reduction of construction cost when lateritic materials were used as aggregate in asphalt concrete pavements. An effort by Jaritngam, Somchainuek, \&Taneerannanon (2014) showed that the cost of construction reduced and strength increased when cement treated laterite soil was used as base course aggregate instead of crushed rock. In a similar research, Biswal, Sahoo, \& Dash (2016) indicated that granular lateritic soil when blended with cement satisfies the Indian Roads Congress (IRC) requirement for base layer.

Thus, if similar results as those found in literatures regarding using lateritic materials in pavement base and sub-base can be expected when used in asphalt pavement surface, cost of construction could be reduced.

The aim of this paper shall be to evaluate the $\mathrm{mx}$ design properties and swell features when submerged laterite rock asphalt concrete mixtures blended with varying amounts of Portland Limestone cement. This is important because of the following reasons: for pavement asphalt construction cost which are expensive as a result of the high cost of granite rock, this study will be useful to reduce the cost of construction of asphalt pavements as laterite rock is less expensive.

Asphalt concrete is known by many different names: hot mix asphalt, plant mix, bituminous mix, bituminous concrete, and many others. It is a combination of two primary ingredients - aggregates and asphalt cement. The aggregates total 90 to 95 percent of the total mixture by weight. They are mixed with 5 to 10 percent asphalt cement to form asphalt concrete. The components of asphalt concrete are explained below:

Bitumen or Asphalt may be defined as a dark brown to black, cement-like semisolid or solid or viscous liquid occurring naturally or produced by the non-destructive distillation of crude oil during petroleum refining (ASTM D8-18, 2018; Wess, Olsen, \& Sweeney, 2004; Ebrahimi, 2010). Different refinery processes, such as the straight distillation process, solvent extraction process etc. may be used to produce bitumen of different consistency and other desirable properties (MAPA, 2017; Lanier, 1998). Depending on the sources and characteristics of the crude oils and on the properties of bitumen required, more than one processing method may be employed (MAPA, 2017). One of the characteristics and advantages of asphalt as an engineering construction and maintenance material is its versatility. Although a semi-solid at ordinary temperature, asphalt may be liquefied by applying heat, dissolving it in solvents or emulsifying it. Bitumen is used extensively in asphalt pavement construction primarily because of its binding characteristics, waterproofing properties and relatively low cost (Mathew \& Rao, 2007). The terms Bitumen or Asphalt may be used interchangeably.

\subsection{Modified Bitumen}

According to Bulatovic, Rek, \& Markovic (2012) certain additives or blend of additives known as bitumen modifiers can improve properties of bitumen and bituminous mixes. Bitumen treated with these modifiers is known as modified bitumen. Polymer Modified Bitumen (PMB) and Crumb Rubber Modified Bitumen (CRMB) are the most common types of modified bitumen used today (MAPA, 2017). The detailed specifications for modified bitumen have been issued by Indian Roads Congress (IRC: SP: 53-1999). It must be noted however, that the performance of PMB and CRMB is dependent on strict control on temperature during construction. Mathew \& Rao (2007) lists some advantages of using modified bitumen:It is less susceptible to daily and seasonal variations in temperature tests are standardized in many specifications, e.g., British specifications, ASTM, Indian Standards, and Europeanstandards. However, all these methods are practically identical and can be used to investigate aggregate used in HMA.

MAPA (2017) describes aggregates as hard, inert materials which include sand, slag, gravel, crushed rock, or rock dust. Asphalt pavements are formed by mixing properly selected and graded aggregates 
with the asphalt binder. Aggregates are the major load bearing components of an asphalt pavement, occupying approximately 95 percent of the mixture by weight (Hicks, et al, 2003).

\subsection{Absorption Characteristics}

According to HP Corporation (N.D) aggregates absorb asphalt to some extent, thereby reducing the effective volumetric percentage of the binder mixtures or the effective application rate in chip seals. These changes can bring about raveling of the pavement. To measure the absorption of aggregate, Caltrans suggests using the Centrifuge Kerosene Equivalent and the Oil Ratio Test (Caltrans, 2007).

\subsection{Laterite Rock Aggregate}

The term Laterite is derived from the Latin word - later, meaning brick. It was first used in 1807 by Buchanan to describe a red iron-rich material found in the southern parts of India. Laterites are widely distributed throughout the world in the regions with high rainfall, but especially in the inter-tropical regions of Africa, Australia, India, South-East Asia and South America, where they generally occur just below the surface of grasslands or forest clearings. Their extension indicates that conditions were favorable for their formation at some point in time in the history of the world, but not necessarily simultaneously in all regions (Maignien, 1966). Alexander et al., (1962) compiled the physical, chemical and morphologicaldefinitions from various researchers and then redefined laterite as a highly weathered material, rich in secondary oxides of iron, aluminum, or both, it is nearly void of bases and primary silicates, but it may contain large amounts of quartz and kaolinite, and it is either hard or capable of hardening on exposure to wetting and drying.

\subsection{Geotechnical Properties of Laterite Soils}

Laterite soil is a product of tropical weathering with red, brown or dark brown colour, with or without nodules or concretions and generally (but not exclusively) found below hardened ferruginous crusts or hardpan (Ola, 1983). Laterite soils are known to be expansive depending on the quantity of halloysite and montmorillonite they contain. This property is also a factor of the composition of the parent rocks and on the laterization process.

The engineering properties of laterite soils are those properties relevant to the engineer and are only determined in the laboratory from the soil samples obtained on the field either by methods of disturbed or undisturbed sampling. They are used for the classification of the soils and subsequently for use (or otherwise) in engineering applications e.g. in foundation and highway construction. Gidigasu (1976) identified that the geotechnical properties of laterite soil are influenced by their genesis, degree of weathering, morphology, chemical and mineralogical composition and also on the environmental factors. These factors are responsible for their variability and inhomogeneity. The engineering properties of laterite soils are only determined in the laboratory (Gidigasu, 1976; Ola, 1983) and they are; particle size analysis and grading carried out via sieve analysis, Atterberg limits tests to determine the plasticity of clay soils, moisture-density relationship done via compaction, permeability tests to determine the ease or otherwise of water movements, the strength tests in service one via unconfined compression and triaxial for plastic soils, direct shear tests for 15 cohesionless soils, consolidation properties to determine its response to modelled foundation load, the California bearing ration, (CBR) tests and so on.

The geotechnical properties of laterites soils were determined from different soil samples by many researchers. Their results further confirmed the variations in properties of the soils being dependent on many factors including the climatic and environmental conditions. Ola 1983; Osinubi, 1998b; Osinubiet al., 2007a,b; Ijimdiya, 2007; Amadi, 2010a,b; Eberemuet al., 2013, have all done in-depth research using laterite soils collected from borrow pits in Shika, Zaria. The liquid limits of these soils were all around $40 \%$; plastic limits were a little in excess of $20 \%$ having Maximum Dry Density (MDD) above $1.7 \mathrm{mg} / \mathrm{m} 3$ corresponding to Optimum Moisture Content (OMC) of about $17.5 \%$, specific gravity between 2.55 and 2.8 and are generally predominantly clays with above $50 \%$ passing through sieve No.200.

Okunlolaet al. (2014) worked on laterite soils collected from borrow pits along Ogbomosho-Ibadan road in south-western Nigeria. Their results showed that the soils had average specific gravity of 2.72 . Atterberg limits tests conducted showed the liquid limit and plastic limits were averagely $49 \%$ and 27 $\%$, respectively. The soil had a Maximum Dry Density (MDD) of between $1.57 \mathrm{~g} / \mathrm{cm} 3$ and $1.87 \mathrm{~g} / \mathrm{cm} 3$ 
corresponding to moisture content of 11 - $16.5 \%$ with California Bearing Ratio (CBR) values of 17$60 \%$ soaked and 42-74 \% un-soaked. Habeebet al. (2012) also collected laterite from Oyo state and investigated the geotechnical properties of the soil for use as subgrade and base materials. $35 \%$ of the soils passed BS No. 200 sieve. The liquid limit was found to be $48 \%$ and plastic limit $25 \%$. MDD was $1.9 \mathrm{Mg} / \mathrm{m} 3$ and OMC $14.3 \%$. Specific gravity of the laterite was 2.65 , CBRun-soaked was $78 \%$.

In the Niger Delta region of Nigeria, the geotechnical properties of laterite soil were investigated by Ugbe (2011). The soil was predominantly A-2 with fines ranging from 14 to $50 \%$ having very low gravel contents $(0-6 \%)$ and thus not suitable as base course material. CBR value was reported to be between 3 and $43 \%$ (soaked condition), MDD 1.7 to $2.14 \mathrm{Mg} / \mathrm{m} 3$, OMC $7.7 \%$ to $18 \%$ and mean specific gravity of 2.62 .

\subsection{Laterite Rock in Asphalt Pavements}

Aginam, Nwakaire,\&Nwajuaku (2015) concluded that according to the USCS (Unified Soil Classification mSystem), the lateritic soils in Anambra centralzoneof Anambra state, Nigeria are classified in groupSC (Clayey sand). Based on the USCSclassification, thesesoils can be used as subgradeand sub-base materials but are not suitable for basecourse of roads. The strength ofthese materials can be improved by applying soil stabilizationtechniques such as addition of cement, lime, fly ash, etc., its concomitant environmental benefits are characteristics that make this method attractive.

\subsection{Mineral Fillers}

Sangiorgiet al (2017) defines mineral filler as those mineral particles which when suspended in bitumen, alter its consistency, and ultimately the character of the pavement. It is generally considered that the number 200sieve (75 micron) can be used as the dividing line between filler, and aggregates particles. In asphalt concretes, as in cement concretes, fillers are the finest particles among the aggregates and their inclusion in bituminous and non-bituminous binders and in aggregate mixtures confers special characteristics to these mixtures. Fillers play a major role in the production of asphalt, in terms of the composition of the mixtures and their physical and mechanical properties (Kandhal\& Parker, 1998). In general, fillers reduce the voids and increase the density, stability and toughness of the concrete mixes. As filler content increases, the brittleness and tendency to crack in service also increase (Al-Saffar, 2013; Grabowski \&Wilanowicz, 2008).

Despite being widely utilized in the production of asphalt, it is still difficult to propose a general classification describing all the functions carried out by fillers used in mixtures. Fillers are the finest part in asphalt concrete mixtures, completing the granulometry, thereby helping to reduce the voids in the mixture (Harris \& Stuart, 1995; Huang, Shu \& Chen, 2007). Various studies and experimental applications have shown that fillers can also perform other important functions, diminishing the asphalt concretes' thermal susceptibility and regulating the thickness and mechanical properties of the film of mastic covering the stone-based aggregates (Zulkati, Diew\&Delai, 2012). Fillers must have certain physical and chemical properties that encourage and strengthen binding between aggregates and bituminous mastic, while also ensuring that the rheological behavior of the latter is optimal at the various operating temperatures (Alvarez, Ovalles, \& Caro, 2012); these are generally properties of commonly used fillers, such as slaked lime, Portland cement, fly ash, quarry dust, and calcium carbonate powder (Little, \&Patersen, 2005).

\section{MATERIALS AND METHODS}

Sources of the materials used and the various testing procedures which are performed in compliance with standard specifications such as ASTM, British Standards, Indian Standards and AASHTO are described. The procedure for Marshall Mix design is also outlined.

\subsection{Sample Collection}

The materials used for this research includes fine and coarse aggregates, bitumen, and filler. The fine aggregate used was sharp sand, with specific gravity of 2.66 , while the coarse aggregate was all-in graded gravel with specific gravity of 2.78 , and having maximum size of a half-inch $(12.7 \mathrm{~mm})$. These aggregates were obtained from the local building materials market at Mile-3, Diobu, Port Harcourt, Rivers State, Nigeria. Laboratory tests carried out on the aggregates included the following: 
Gradation analysis(Sieve Analysis)

\subsection{Specific Gravity Test}

The binder used was grade 60/70 penetration bitumen as recommended by ASTM D1559 for Highway Pavements. This binder was obtained from Julius Berger Construction Company Port Harcourt, Rivers State, Nigeria. Within the scope of this study, the tests carried out on binder included;

- Specific gravity Test

- Penetration Test

- Viscosity Test

- Softening Point Test.

The filler used was Portland cement and Fly Ash, obtained from the local materials market in Diobu, Port Harcourt, and Eleme Petro-Chemical all in Rivers State, Nigeria. Only Specific Gravity test was carried out on the pozzolans.

\subsection{Soecific Gravity of the Portland Limstone Cement}

For the mineral filler, the pycnometer method was used to obtain the weight of a given volume of the modifier and also used to obtain the weight of an equal volume of water. Specific gravity was thus obtained by dividing the weight of the modifier by the weight of an equal volume of water.

\subsection{Presentation of Model}

This section highlights the models used in the determination of the Mix Design properties (stability and density) of the modified and unmodified asphalt concrete in addition to the conventional densitystability analysis. The Stability and flow results were obtained using the Marshall apparatus, which simultaneously displays the loading applied to the samples as well as their displacements

The results from these tests are then used to carry out the density-stability analysis, after the determination of the other linking properties as presented in this study

\subsection{Determination of Optimum Binder Content (Obc)}

Vital to asphalt concrete mix design is the determination of Optimum Binder Content (OBC) because it sets a basis for the comparison whether a particularmix design should be accepted or rejected based on minimum requirements as per design specification. It is on this basis that the OBC was determined. The average values of Bulk Specific Gravity, Stability, Flow, Air Voids, VMA, and VFB obtained were plotted separately against the binder contents and a smooth curve drawn through the plotted values. The OBC for the HMA mixture was determined by taking the average value of the following three bitumen contents found form the graphs plotted:

- Binder content corresponding to maximum stability(x)

- Binder content corresponding to maximum bulk specific gravity (y)

- Binder content corresponding to the median of designed limits of percent air voids (z)

By applying the formula the stability value, flow value, density and air voids were then checked for suitability with Marshall Mix design specifications.

$\mathrm{OBC}=1 / 3(\mathrm{X}+\mathrm{Y}+\mathrm{Z})$.

\subsection{Modified HMA Concrete Preparation}

The procedure adopted for the preparation of the modified Marshall Specimen is the same as that used in the control mixtures described above. Marshall Stability test is conducted on the stabilized HMA in all samples of $100 \mathrm{~mm}$ diameter and $63.5 \mathrm{~mm}$ height by applying 75 blows on each face as per ASTM procedure (ASTM D1559, 2004). These specimens were prepared by mixing the filler material with the graded aggregates at optimum binder content. The filler content in these specimens were varied from $0.5 \%-3 \%$ by weight of aggregates. The mixing and compaction temperatures are kept as $165^{\circ} \mathrm{C}$ and $150^{\circ} \mathrm{C}$ respectively. After compaction, the samples were cured in air before Marshall Stability tests were conducted on them. 


\subsection{Determination of Mix Design Properties}

In this study, apart from stability-flow test, the properties that are of interest include Theoretical specific gravity $\left(G_{t}\right)$, Bulk Modulus $\left(G_{m b}\right)$, Bulk Density $(\rho)$, Effective specific gravity (Gse), Voids in Total Mixture $(V T M)$, Volume of Bitumen $\left(V_{b}\right)$, Effective bitumen content (Pbe), Void in Mineral Aggregate (VMA), and Voids Filled with Asphalt $(V F B)$. These calculations are discussed next.

Theoretical specific gravity of the mix $\left(G_{t}\right)$ : The theoretical specific gravity $\left(G_{t}\right)$ is the specific gravity without considering air voids, and was obtained by applying known models, other tables and graphs of gradation, specific gravities and the filler fineness modulus are as contained in the appendice.

\section{RESUlts}

The values of un-soaked Mix Design Properties, and Swelling Index (soaked condition) for modified mixes were applying equation 3.11 and 3.12 and the results are given as follows:

Results of Mix Design Properties for modified mixes

Table AA. Results for OPC modified mix-Design Properties at varying modifier content

\begin{tabular}{|c|c|c|c|c|c|c|}
\hline $\begin{array}{c}\text { MOD. } \\
\text { CONTENT }(\%)\end{array}$ & $\begin{array}{l}\text { STABILITY } \\
(\mathrm{N})\end{array}$ & $\begin{array}{c}\text { DENSITY } \\
\left(\mathrm{KG} / \mathrm{M}^{3}\right)\end{array}$ & $\begin{array}{l}\text { AIRVOID } \\
(\%)\end{array}$ & $\operatorname{VTM}(\%)$ & VMA $(\%)$ & FLOW (MM) \\
\hline 0 & 14469 & 2211 & 4.44 & 10.256 & 16.314 & 8.17 \\
\hline 2 & 14903.07 & 2227 & 4.26 & 9.601 & 15.703 & 7.98 \\
\hline 4 & 15613.43 & 2250 & 3.91 & 8.65 & 14.816 & 7.48 \\
\hline 6 & 19965.15 & 2265 & 3.39 & 8.065 & 14.27 & 6.6 \\
\hline 8 & 18368.05 & 2285 & 3.08 & 7.237 & 13.499 & 6.144 \\
\hline 10 & 14353.25 & 2206 & 3.87 & 10.132 & 14.719 & 7.92 \\
\hline
\end{tabular}

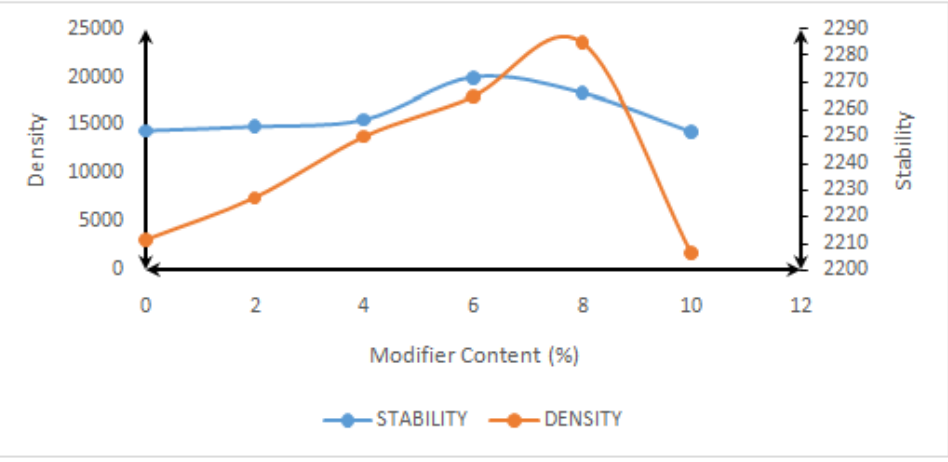

Figure AA.1. Graph of Density and Stability of Modified Mixes

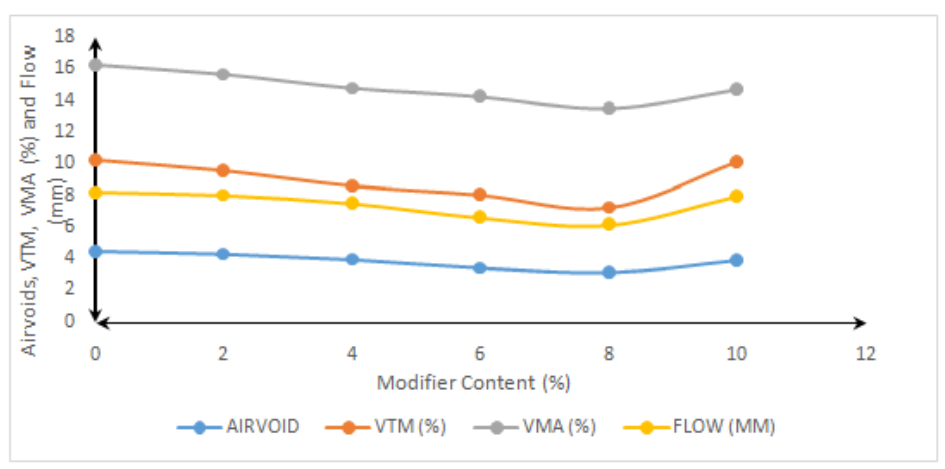

Figure AA.2. Graph of Air-voids, VTM, VMA and Flow of Modified Mixes

\section{DISCUSSION}

\subsection{Variation of Marshal Stability at Varying Modifier Content and Soaking Days}

As illustrated in figure AA.1 and, stability of the modified mixes increased linearly with increasing filler content for all categories of soaking. From table 4.AA.1 and your d, it is seen that for the unsoaked mixes stability varied by $3 \%$ from $14469 \mathrm{~N}$ for the unmodified mix (Day 0) to $14903 \mathrm{~N}$ upon addition of $2 \%$ OPC. Addition of $4 \%$ and $6 \%$ OPC further increased stability by $8 \%$ and $38 \%$ to 
Laterite Rock Modified Asphalt Concrete Mix Design Properties and Swell Behaviour under Soaked Conditions for Rural Roads

$15613 \mathrm{~N}$ and $19965 \mathrm{~N}$ respectively. However, at $8 \%$ and $10 \%$ OPC content, stability varied by $27 \%$ and $1 \%$ to $18368 \mathrm{~N}$ and $14353 \mathrm{~N}$ respectively. Indicating that further increase in OPC content would cause a corresponding decrease in the stability of the modified asphalt concrete mix. Then behaviour was identified with respect to the flowwhich is a measure of deformation expressed in units of $0.25 \mathrm{~mm}$ between no load and maximum load carried by the sample during stability-flow test.

The relationship between bulk density and mineral filler is illustrated in table 4.AA.1. It is seen that bulk density increased by $1.1 \%$ upon addition of $2 \%$ OPC content; $1.8 \%$ at $4 \%$ OPC content; $3.1 \%$ at $6 \%$ OPC content; $4 \%$, at $8 \%$ OPC content where it maximizes; then drops by $4.6 \%$ at $10 \%$ OPC content. This result is due to the fact that as filler content increases, the air voids in the mix reduces and the mix becomes denser. Additionally, OPC has a high specific gravity; hence it would increase the density of the mixture.

\subsection{Variation of Air-Voids (Pa), VTM, VMA and Flow at varying OPC content}

Figure AA2 shows the variation of voids and flow in the mixture upon addition of OPC. From figure AA2, it is seen that compared with the control mix $(0 \%)$, total voids in mineral aggregates (VTM) decreased linearly with increasing OPC content. VTM which was at $8.2 \%$ for the unmodified mix reduced to $7.2 \%$ after adding $2 \%$ OPC; $6.6 \%$ at $4 \%$ content; $5.4 \%$ at $6 \%$ OPC content; $4.6 \%$, at $8 \%$ OPC content; and slightly increases by $2.9 \%$ upon addition of $10 \%$ OPC content. The decrease is explained by the high bulk density of the mix and indicates that OPC reduces the percentage of voids in the mix. The implication is that the mixture becomes less susceptible to stripping since there is less void to allow percolation of water in the asphalt concrete mix.

Similarly, from figure AA2, the voids in mineral aggregates (VMA) decreased linearly with increasing OPC content. VMA which was at $17 \%$ decreased to $16.1 \%$ at $2 \%$ OPC content; $15.5 \%$ at $4 \%$ OPC content; $14.5 \%$ at $6 \%$ OPC content; $13.7 \%$, at $8 \%$ OPC content; and then increased slightly by $12.3 \%$ upon addition of $10 \%$ OPC content. Again, this implies that the addition of OPC reduces the percentage of voids in mineral aggregates in the mix; which is a combination of total volume air voids and volume of bitumen in the mix. Thus, the mix is less susceptible to known pavement distresses.

Again in figure AA2, we see a linear decrease in the percentage of air voids filled in asphalt $(\mathrm{Pa})$ as OPC content increases. The Pa represents the voids in the aggregate framework within the mix, which has been occupied by the matrix (binder +filler). Results show that Pa decreased from $51.6 \%$ for the unmodified mix to $55.2 \%$ at $2 \%$ OPC content; $57.4 \%$ at $4 \%$ OPC content; $62.5 \%$ at $6 \%$ OPC content; $66.6 \%$, at $8 \%$ OPC content; and increased by $7 \%$ upon addition of $10 \% 10$ content.

Table BB. Results for OPC modified mix-Design Properties at varying modifier content

\begin{tabular}{|c|c|c|c|c|c|c|}
\hline OPC & Day 0 & Day1 & Day2 & Day3 & Day4 & Day5 \\
\hline 0 & 0 & 3.8 & 4.1 & 4.4 & 4.7 & 4.7 \\
\hline 2 & 0 & 3.6 & 3.9 & 4 & 4.1 & 4.6 \\
\hline 4 & 0 & 3.3 & 3.4 & 3.7 & 3.9 & 4.2 \\
\hline 6 & 0 & 2.8 & 3.1 & 3.4 & 3.7 & 4.1 \\
\hline 8 & 0 & 2.6 & 2.9 & 3.1 & 3.4 & 3.7 \\
\hline 10 & 0 & 2.3 & 2.5 & 2.8 & 3.2 & 3.4 \\
\hline
\end{tabular}

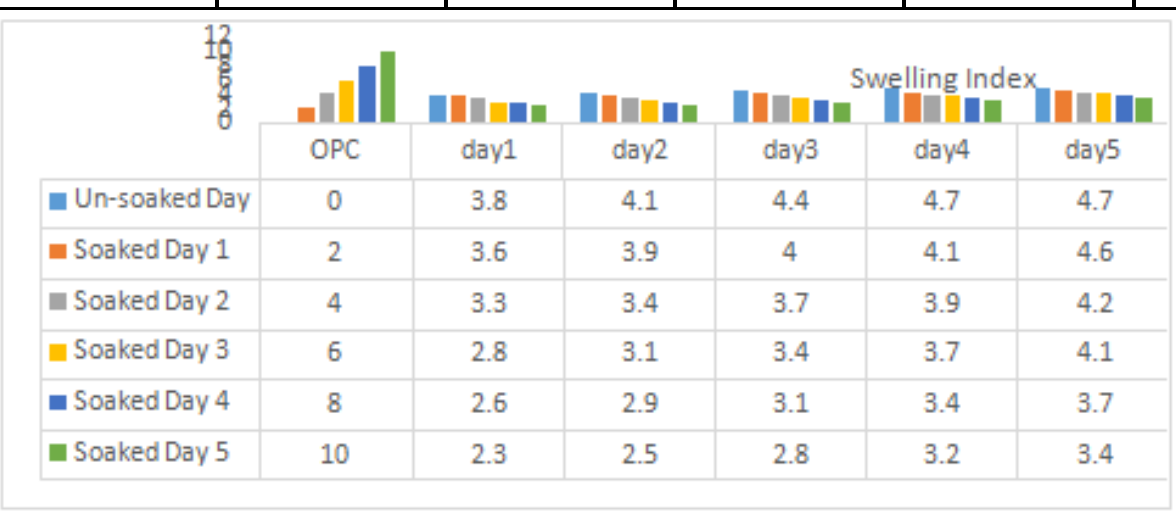

Figure BB. Graph of Swelling Index against OPC content, Soaked for 5Days 


\subsection{Variation of Swelling Index at Varying Modifier Content and Soaking Days}

Table BB and figure BB shows the variation of swelling across different OPC content and soaking days for the unmodified and modified samples. For the soaked mixes, swelling index after one day of soaking was $3.8 \%$ for the unmodified mix. Upon addition of $2 \%, 4 \%, 6 \%, 8 \%$ and $10 \%$ OPC by weight of aggregates, swelling index reduced to $3.6 \%, 3.3 \%, 2.8 \%, 2.6 \%$ and $2.3 \%$ respectively. This indicates that addition of OPC causes a steady decrease in the swelling of the asphalt concrete mix during the period of submergence.

After two days of submergence, swelling index was $4.1 \%$ for the unmodified mix. Again, addition of $2 \%, 4 \%, 6 \%, 8 \%$ and $10 \%$ OPC by weight of aggregates reduced swelling to $3.9 \%, 3.4 \%, 3.1 \%$, $2.9 \%$, and $2.5 \%$ respectively; also indicating that addition of OPC causes a steady decrease in the swelling of the asphalt concrete mix during the period of submergence.

Similarly, for three days of submergence, swelling index was recorded as $4.4 \%$ for the unmodified mix. Addition of $2 \%, 4 \%, 6 \%, 8 \%$ and $10 \%$ OPC by weight of aggregates once again reduced swelling to $4.0 \%, 3.7 \%, 3.4 \%, 3.1 \%$, and $2.8 \%$ respectively; also indicating that addition of OPC causes a steady decrease in the swelling of the asphalt concrete mix during the period of submergence.

Also, for four days of submergence, swelling index was recorded as $4.7 \%$ for the unmodified mix. Again, addition of $2 \%, 4 \%, 6 \%, 8 \%$ and $10 \%$ OPC by weight of aggregates reduced swelling to $4.1 \%$, $3.9 \%, 3.7 \%, 3.4 \%$, and $3.2 \%$ respectively; also indicating that addition of OPC causes a steady decrease in the swelling of the asphalt concrete mix during the period of submergence.

Lastly, for five days of submergence, swelling index was recorded as $4.7 \%$ for the unmodified mix. Addition of $2 \%, 4 \%, 6 \%, 8 \%$ and $10 \%$ OPC by weight of aggregates once again reduced swelling to $4.6 \%, 4.2 \%, 4.1 \%, 3.7 \%$, and $3.4 \%$ respectively; also indicating that addition of OPC causes a steady decrease in the swelling of the asphalt concrete mix during the period of submergence.

The results obtained for the swelling index of unmodified and asphalt concrete mixes at various soaking periods indicate that the swelling index decreases linearly as the OPC filler content increases irrespective of the period of submergence. This clearly shows that OPC can serve as an ideal filler material to achieve swell reduction in asphalt concrete mixtures.

\section{REFERENCES}

[1] Ephraim, M. E., Adoga, E. A., \& Rowland-Lato, E. O. (2016). Strength of Laterite Rock Concrete. American Journal of Civil Engineering and Architecture,, 4(2), 54-61. doi:10.12691/ajcea-4-2-3.

[2] Gidigasu, M. (1976). Laterite Soil Engineering:Pedogenesis and Engineering Principles. . Amsterdam: Elsevier Scientific Publication Company.

[3] Grabowski, W., \& Wilanowicz, J. (2008). The structure of mineral filler and their stiffening properties in filler-bitumen mastics. Construction and Building Materials, 41, 793-804. Materials and Structures, 41, 793-804.

[4] Eberemu, A. O., Edeh, J. E., \& Gbolokun, A. O. (2013). The Geotechnical Properties of Lateritic Soil Treated with Crushed Glass Cullet. Advance Materials Research, 824, 21-28.

[5] Ephraim, M. E., Adoga, E. A., \& Rowland-Lato, E. O. (2016). Strength of Laterite Rock Concrete. American Journal of Civil Engineering and Architecture, 4(2), 54-61. doi:10.12691/ajcea-4-2-3.

[6] Gidigasu, M. (1976). Laterite Soil Engineering:Pedogenesis and Engineering Principles. . Amsterdam: Elsevier Scientific Publication Company.

[7] Grabowski, W., \& Wilanowicz, J. (2008). The structure of mineral filler and their stiffening properties in filler-bitumen mastics. Construction and Building Materials, 41, 793-804. Materials and Structures, 41, 793-804.

[8] Habeeb, A. O., Olabambe, A. A., \& Oladipupo, S. O. (2012). Investigation of the Geotechnical Engineering Properties of Laterite as Sub-grade and Base Material for Road Construction in Nigeria. Civil and Environmental Research. Civil and Environmental Research, 2(8), 23-31.

[9] Harris, B. M., \& Stuart, K. D. (1995). Analysis of mineral fillers and mastics used in stone matrix asphalt. Williamsburg, VA: Association of Asphalt Paving Technologists.

[10] Hicks, R. G., Curren, P., \& Lundy, J. R. (2003). Asphalt Paving Design Guide. Oregon: Asphalt Pavement Association of Oregon.

[11] HP Corporation. (n.d.). HP Bitumen Handbook. Mumbai: Hindustan Petroleum Inc. 
Laterite Rock Modified Asphalt Concrete Mix Design Properties and Swell Behaviour under Soaked Conditions for Rural Roads

[12] Ijimdiya, T. S. (2007). Effect of Oil contamination on soil properties. Book of Abstracts 5th Nigerian Material Congress. Ile-Ife, Osun.

[13] Jaritngam, S., Somchainuek, O., \& Taneerananon, P. (2014). Feasibility of Laterite-Cement Mixture as Pavement Base Course Aggregate. IJST, Transactions of Civil Engineering,, 38(C1), 275-284.

[14] Lemougna, P. N., Melo, U. F., Kamseu, E., \& Tchamba, A. B. (2011). Laterite Based Stabilized Products for Sustainable Building Applications in Tropical Countries: Review and Prospects for the Case of Cameroon. Sustainability, 3, 293-305. doi:doi:10.3390/su3010293

[15] Okunlola, I. A., Idris-Nda, A., Dindey, A. O., \& Kolawole, L. L. (2014). Geotechnical and geochemical properties of lateritic profile on migmatite gneisis along Ogbomosho - Ilorin Highway, Southwestern Nigeria. African Journal of Geographical Science, 1(1), 1-6.

[16] Ola, S. A. (1983). The Geotechnical Properties of Black Cotton Soils of North Eastern Nigeria. In S. A. Ola (Ed.), Tropical Soils of Nigeria in Engineering Practice (pp. 160-178). Rotterdam: Balkama.

[17] Osinubi, K. J. (1998). Permeability of lime-treated lateritic soil. Journal of Transportation Engineering, ASCE, 124(2), 465-469.

[18] Osinubi, K. J., \& Stephen, A. T. (2007). Influence of Compactive Efforts on Bagasse Ash Treated Black Cotton Soil. Nigerian Journal of Soil and Environmental Research, 7, 92-101.

[19] Ugbe, F. (2011). Basic Engineering Geological Properties of Lateritic Soils from Western Niger Delta. Research Journal of Environmental and Earth Sciences, 3(5), 571-577.

\section{APPENDIX BELOW}

Rivers State University

Nkpolu, Oroworukwo, Portharcourt

Department of Civil Engineering

Civil Engineering Laboratory

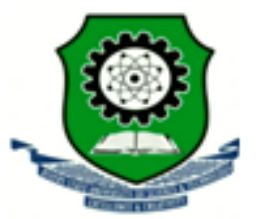

- $\quad$ Specific Gravity Test Form (Laterite)

BS 1377:1975

\begin{tabular}{|c|c|c|}
\hline TEST PARAMETERS & TEST 1 & TEST 2 \\
\hline WEIGHT OF BOTTLE & & \\
\hline $\operatorname{ONLY}(\mathrm{g}) \quad \ldots \ldots \ldots \ldots \ldots \mathrm{M}_{1}$ & 448.2 & 448.2 \\
\hline WEIGHT OF BOTTLE AND DRY & & \\
\hline $\operatorname{SAMPLE~}(\mathrm{g}) \quad \ldots \ldots \ldots \ldots \ldots \mathrm{M}_{2}$ & 662.4 & 649.2 \\
\hline WEIGHT OF BOTTLE, SAMPLE & & \\
\hline $\operatorname{AND} W A T E R(g) \quad \ldots \ldots \ldots . . M_{3}$ & 817.4 & 807.3 \\
\hline WEIGHT OF BOTTLE AND & & \\
\hline WATER $(\mathrm{g}) \quad \ldots \ldots \ldots \ldots \mathrm{M}_{4}$ & 674.4 & 674.7 \\
\hline$G_{1}=\frac{M_{2}-M_{1}}{2}$ & & \\
\hline $\mathrm{u}_{\mathrm{s}}=\overline{\left(M_{4}-M_{1}\right)-\left(M_{3}-M_{2}\right)}$ & 3.0 & 2.9 \\
\hline AVERAGE $\mathrm{G}_{\mathrm{s}}$ & \multicolumn{2}{|c|}{2.95} \\
\hline
\end{tabular}

Tested By: Nyebuchi, A. Daniel Date: 19-30/2/2020

Checked By: Dr. E.A. Igwe

- Specific Gravity Test Form (Sand)

BS:1377:1975

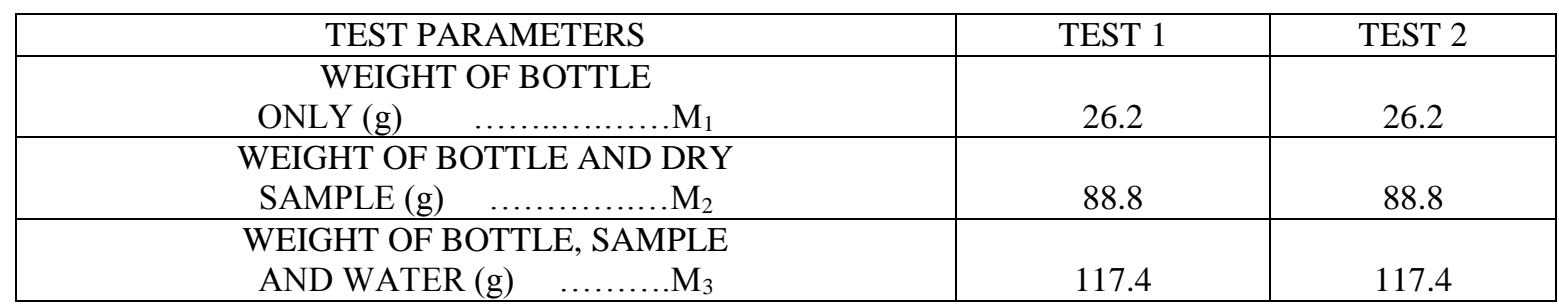


Laterite Rock Modified Asphalt Concrete Mix Design Properties and Swell Behaviour under Soaked Conditions for Rural Roads

\begin{tabular}{|c|c|c|}
\hline $\begin{array}{c}\text { WEIGHT OF BOTTLE AND } \\
\text { WATER }(\mathrm{g}) \quad \ldots \ldots \ldots \ldots . \mathrm{M}_{4}\end{array}$ & 78.3 & 78.3 \\
\hline $\mathrm{G}_{\mathrm{s}}=\frac{M_{2}-M_{1}}{\left(M_{4}-M_{1}\right)-\left(M_{3}-M_{2}\right)}$ & 2.66 & 2.66 \\
\hline AVERAGE G & \multicolumn{2}{|c|}{2.66} \\
\hline
\end{tabular}

- $\quad$ Specific Gravity Test Form (Opc)

BS:1377:1975

\begin{tabular}{|c|c|c|}
\hline TEST PARAMETERS & TEST 1 & TEST 2 \\
\hline WEIGHT OF DENSITY BOTTLE $\left(\mathrm{W}_{1}\right) \ldots . . \mathrm{gms}$ & 25 & 25 \\
\hline WEIGHT OF BOTTLE AND DRY & & 70 \\
\hline SAMPLE $\left(\mathrm{W}_{2}\right) \ldots . . \mathrm{gms}$ & 70 & 105.8 \\
\hline WEIGHT OF BOTTLE, SAMPLE AND WATER $\left(\mathrm{W}_{3}\right) \ldots . . \mathrm{gms}$ & 105.6 & 3.17 \\
\hline SPECIFIC GRAVITY $\mathrm{G}_{\mathrm{s}}=\frac{\mathrm{W}_{2}-\mathrm{W}_{1}}{50-\left(\mathrm{W}_{3}-\mathrm{W}_{2}\right)}$ & 3.13 & 3.15 \\
\hline AVERAGE $\mathrm{G}_{\mathrm{s}}$ & \multicolumn{2}{|c|}{} \\
\hline
\end{tabular}

- Water Absorption Test Form of Coarse Aggregates

ASTM C127

BS 812:1997

Sample: Laterite Rock

\begin{tabular}{|c|c|c|}
\hline TEST PARAMETERS & TEST 1 & TEST 2 \\
\hline $\begin{array}{c}\text { WEIGHT OF OVEN-DRY SAMPLE (DRY MASS) AND CONTAINER } \\
\text { WEIGHING IN AIR }(\mathrm{g}) \ldots \ldots \ldots \ldots \ldots \ldots \ldots \ldots \ldots \ldots . \ldots\end{array}$ & 1200 & 650 \\
\hline $\begin{array}{c}\text { WEIGHT OF SATURATED SURFACE-DRYING SAMPLE AND } \\
\text { CONTAINER WEIGHTING IN AIR }(\mathrm{g}) \ldots \ldots \ldots \ldots \ldots \ldots \ldots \ldots \ldots . . . \ldots\end{array}$ & 1228.4 & 668 \\
\hline WATER ABSORPTION $(\%)=\frac{B-A}{A} \times \frac{100}{1}$ & 2.3 & 2.7 \\
\hline AVERAGE WATER ABSORPTION $(\%)$ & \multicolumn{2}{|c|}{2.55} \\
\hline
\end{tabular}

- Water Absorption Test Form of Coarse Aggregates

ASTM C127

BS 812:1997

Sample: Granite

\begin{tabular}{|c|c|c|}
\hline TEST PARAMETERS & TEST 1 & TEST 2 \\
\hline $\begin{array}{c}\text { WEIGHT OF OVEN-DRY SAMPLE (DRY MASS) AND CONTAINER } \\
\text { WEIGHING IN AIR }(\mathrm{g}) \ldots \ldots \ldots \ldots \ldots \ldots \ldots \ldots \ldots \ldots\end{array}$ & 740 & 782 \\
\hline $\begin{array}{l}\text { WEIGHT OF SATURATED SURFACE-DRYING SAMPLE AND } \\
\text { CONTAINER WEIGHTING IN AIR }(\mathrm{g}) \ldots \ldots \ldots \ldots \ldots \ldots \ldots \ldots \ldots \ldots \mathrm{B}\end{array}$ & 746 & 789 \\
\hline WATER ABSORPTION $(\%)=\frac{B-A}{A} \times \frac{100}{1}$ & 0.82 & 0.90 \\
\hline AVERAGE WATER ABSORPTION (\%) & \multicolumn{2}{|c|}{0.86} \\
\hline
\end{tabular}

- $\quad$ Standard Penetration Test Form

BS: 4691/3235

\begin{tabular}{|c|c|c|c|c|}
\hline TEST PARAMETERS & TEST 1 & TEST 2 & TEST 3 & Average \\
\hline Test Temperature $\left({ }^{0} \mathrm{C}\right)$ & 25 & 25 & 25 & 25 \\
\hline Time (s) & 5 & 5 & 5 & 5 \\
\hline Penetration & 68 & 65 & 67 & 66.7 \\
\hline
\end{tabular}

- Bitumen Viscosity Test Form

BS: 4693

\begin{tabular}{|c|c|c|c|}
\hline TEST PARAMETERS & TEST 1 & TEST 2 & Average \\
\hline Test Temperature $\left({ }^{\circ} \mathrm{C}\right)$ & 60 & 60 & 60 \\
\hline Volume of bitumen that falls inside beaker & 50 & 50 & 50 \\
\hline Time $(\mathrm{s})$ & 68.1 & 70.5 & 69.3 \\
\hline
\end{tabular}


Laterite Rock Modified Asphalt Concrete Mix Design Properties and Swell Behaviour under Soaked Conditions for Rural Roads

- $\quad$ Bitumen Softening Point Test Form

BS: $4691 / 3235$

\begin{tabular}{|c|c|c|c|c|}
\hline TEST PARAMETERS & TEST 1 & TEST 2 & TEST 1 & Test 2 \\
\hline & Ball 1 & Ball 2 & Ball 1 & Ball 2 \\
\hline Temperature at softening point & 50 & 49 & 49 & 50 \\
\hline Softening Point & \multicolumn{5}{|c|}{49.5} \\
\hline
\end{tabular}

- $\quad$ Specific Gravity Test Form (Bitumen)

BS: 1377:1975

\begin{tabular}{|c|c|c|}
\hline TEST PARAMETERS & TEST 1 & TEST 2 \\
\hline WEIGHT OF DENSITY BOTTLE $\left(\mathrm{W}_{1}\right) \ldots . . \mathrm{gms}$ & 41 & \\
\hline WEIGHT OF BOTTLE AND SAMPLE $\left(\mathrm{W}_{2}\right) \ldots . . \mathrm{gms}$ & 58.6 & \\
\hline WEIGHT OF BOTTLE, SAMPLE IN WATER $\left(\mathrm{W}_{3}\right) \ldots \ldots \mathrm{gms}$ & 17.2 & \\
\hline SPECIFIC GRAVITY $\mathrm{G}_{\mathrm{s}}=\frac{\mathrm{W}_{2}-\mathrm{W}_{1}}{\mathrm{~W}_{3}}$ & 1.02 & \\
\hline
\end{tabular}

\section{Grading of Aggregates}

- $\quad$ Gradation of Sand (Sample Size $=1200 \mathrm{~g})$

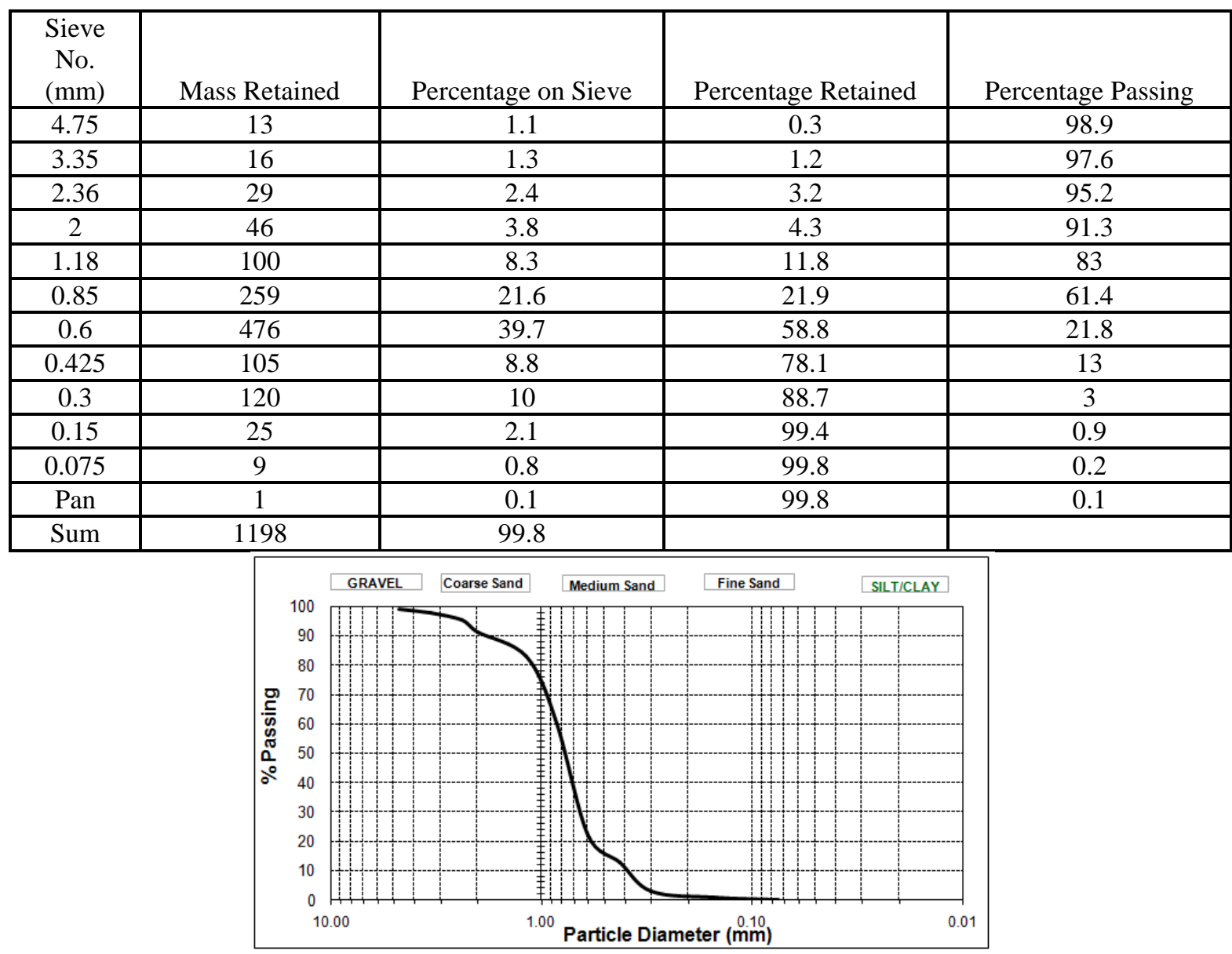

Particle Size distribution for Sand

- $\quad$ Gradation of Laterite (Sample Size $=1200 \mathrm{~g}$ )

\begin{tabular}{|c|c|c|c|}
\hline $\begin{array}{c}\text { Sieve No. } \\
(\mathrm{mm})\end{array}$ & Mass Retained & Percentage on Sieve & Percentage Passing \\
\hline 25.4 & 0 & 0 & 100 \\
\hline 19 & 0 & 0 & 100 \\
\hline 13.2 & 115 & 8.9 & 91.1 \\
\hline 9.5 & 586 & 47.8 & 43.3 \\
\hline 6.7 & 208 & 26.5 & 16.8 \\
\hline
\end{tabular}


Laterite Rock Modified Asphalt Concrete Mix Design Properties and Swell Behaviour under Soaked Conditions for Rural Roads

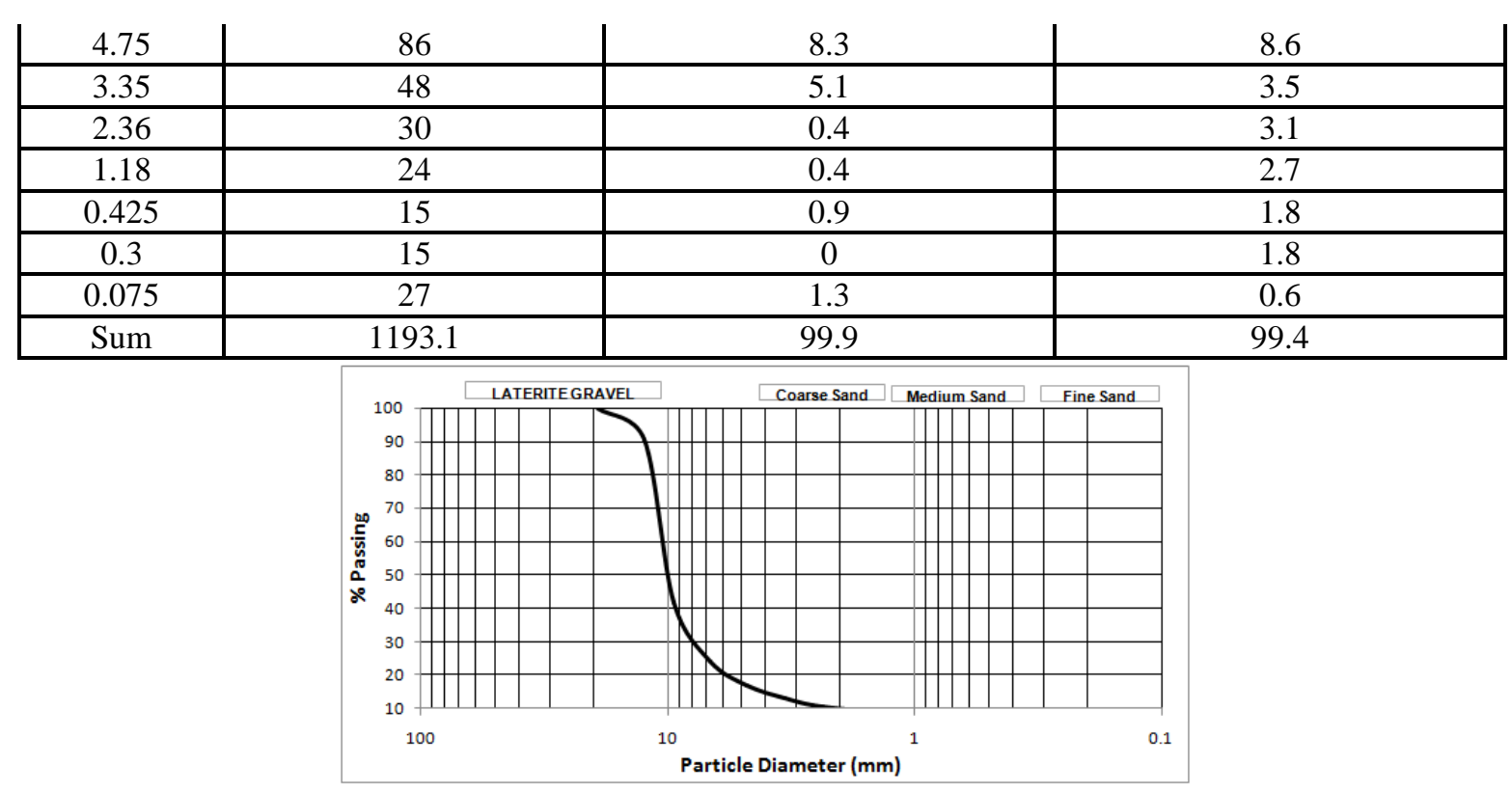

Blending of Aggregates

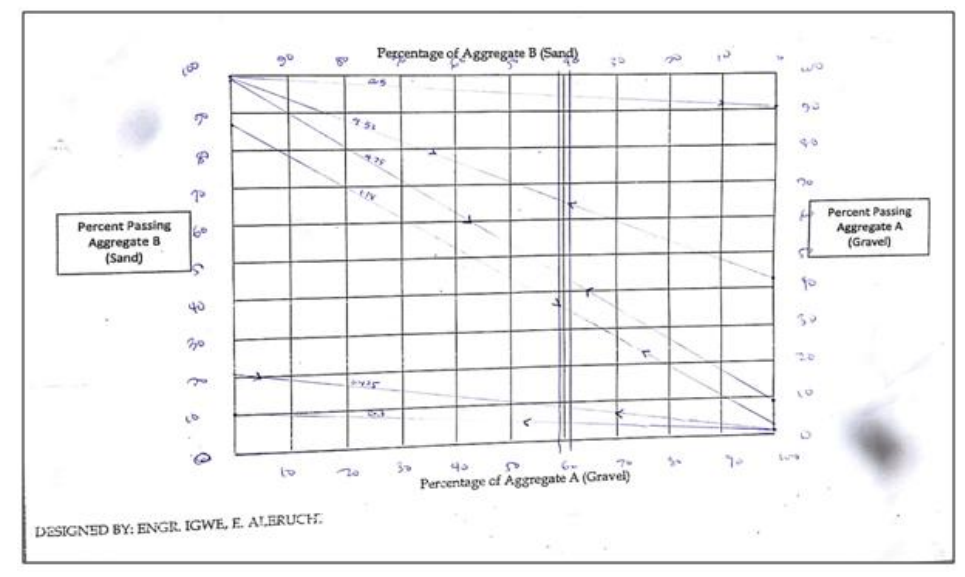

Straight line method for determining mix proportion

- Schedule of Mix proportion for Aggregates (Laterite \& sand)

\begin{tabular}{|c|c|c|c|c|c|c|}
\hline $\begin{array}{c}\text { Sieve } \\
\text { (in.) }\end{array}$ & $\begin{array}{c}\text { Sieve } \\
(\mathrm{mm})\end{array}$ & $\begin{array}{c}\text { Specification } \\
\text { Limit }\end{array}$ & $\begin{array}{c}\text { \% passing } \\
\text { Aggregate A } \\
\text { (Gravel) }\end{array}$ & $\begin{array}{c}\text { \% passing } \\
\text { Aggregate B } \\
\text { (Sand) }\end{array}$ & $\begin{array}{c}\text { Mix Proportion } \\
(0.62 \text { A+0.38B) }\end{array}$ & Tolerance \\
\hline $3 / 4 "$ & 19.1 & 100 & 100.0 & 100.0 & 100.0 & \pm 6 \\
\hline $1 / 2 "$ & 12.7 & $76-92$ & 90.4 & 100.0 & 94.0 & \pm 6 \\
\hline $3 / 8 "$ & 9.52 & $64-79$ & 41.6 & 100.0 & 63.8 & \pm 5 \\
\hline No. 4 & 4.75 & $40-60$ & 17.1 & 98.9 & 48.2 & \pm 5 \\
\hline No.10 & 1.18 & $23-37$ & 8.6 & 83.0 & 36.9 & \pm 4 \\
\hline No. 40 & 0.425 & $7-20$ & 6.3 & 13.0 & 8.8 & \pm 4 \\
\hline No. 80 & 0.300 & $5-13$ & 4.8 & 3.0 & 4.1 & \pm 3 \\
\hline No. 200 & 0.075 & $3-8$ & 3.8 & 0.2 & 2.4 & \pm 1.5 \\
\hline \multicolumn{2}{|c|}{ Filler } & & & & & \\
\hline
\end{tabular}

- Summary of Mix Properties for Unmodified Asphalt Concrete (Granite)

\begin{tabular}{|c|c|c|c|c|c|c|c|}
\hline $\begin{array}{c}\text { Binder } \\
\%\end{array}$ & $\mathrm{G}_{\mathrm{mb}}$ & $\begin{array}{c}\text { Stability } \\
(\mathrm{N})\end{array}$ & $\begin{array}{c}\text { Density } \\
\left(\mathrm{kg} / \mathrm{m}^{3}\right)\end{array}$ & Flow $(\mathrm{mm})$ & VTM (\%) & VMA (\%) & VFA $(\%)$ \\
\hline 4.0 & 2.103 & 15790 & 2103 & 0.92 & 11.82 & 20.40 & 52.63 \\
\hline 4.5 & 2.246 & 30480 & 2246 & 1.06 & 4.66 & 14.97 & 71.10 \\
\hline 5.0 & 2.183 & 23603 & 2183 & 1.40 & 6.23 & 17.37 & 90.11 \\
\hline 5.5 & 2.154 & 17670 & 2154 & 2.03 & 6.36 & 18.45 & 85.11 \\
\hline 6.0 & 2.154 & 16942 & 2154 & 1.87 & 5.29 & 18.47 & 71.38 \\
\hline
\end{tabular}


Laterite Rock Modified Asphalt Concrete Mix Design Properties and Swell Behaviour under Soaked Conditions for Rural Roads
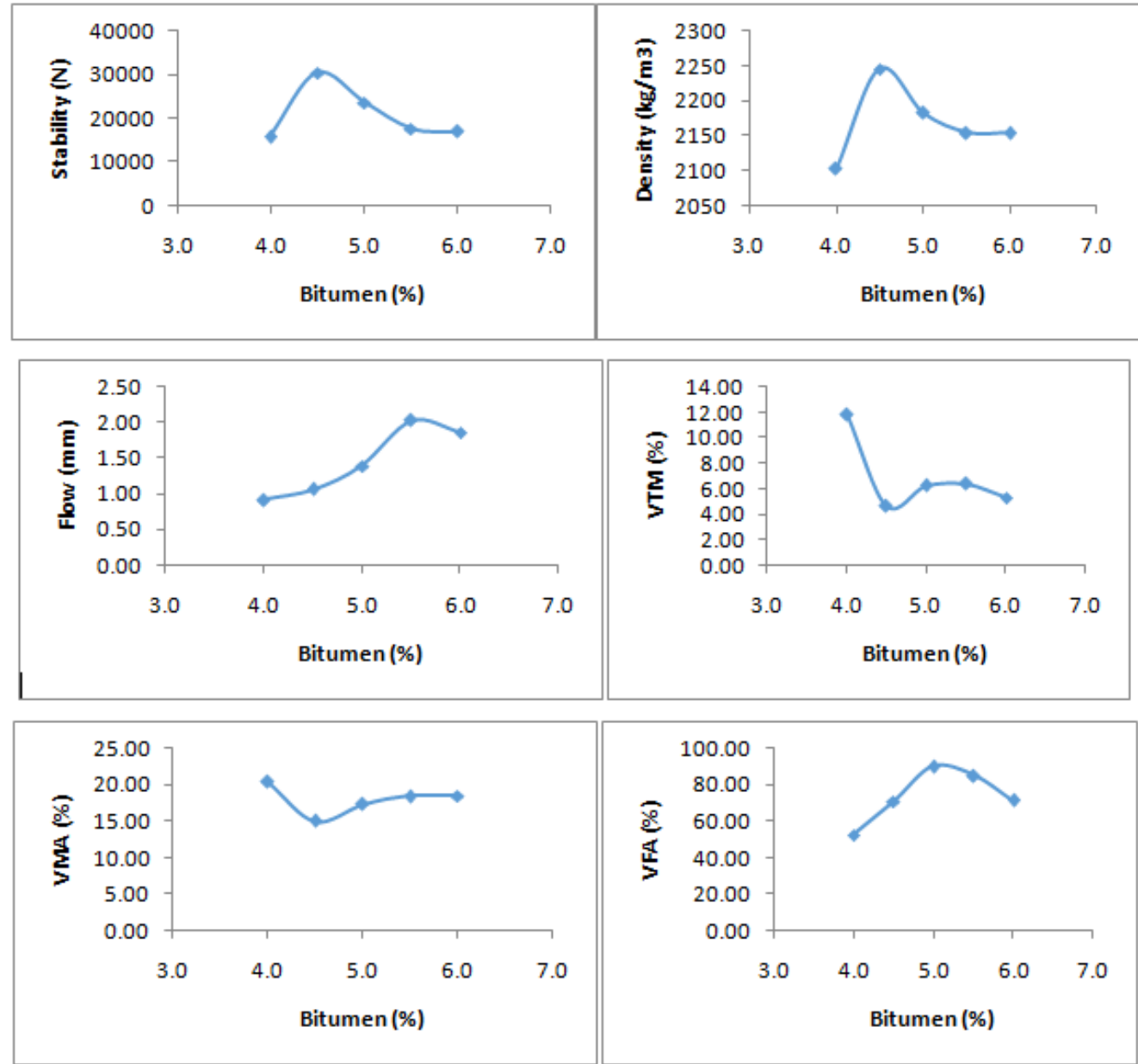

- Summary of Mix Properties for Unmodified Asphalt Concrete (Laterite)

\begin{tabular}{|c|c|c|c|c|c|c|c|}
\hline $\begin{array}{c}\text { Binder } \\
\%\end{array}$ & $\mathrm{G}_{\mathrm{mb}}$ & Stability (N) & $\begin{array}{c}\text { Density } \\
\left(\mathrm{kg} / \mathrm{m}^{3}\right)\end{array}$ & Flow (mm) & VTM (\%) & VMA (\%) & VFA (\%) \\
\hline 4.0 & 2.202 & 20360 & 2202 & 1.75 & 13.63 & 16.64 & 18.09 \\
\hline 4.5 & 2.309 & 29505 & 2309 & 2.33 & 8.30 & 12.59 & 34.07 \\
\hline 5.0 & 2.386 & 36730 & 2386 & 2.68 & 4.07 & 9.67 & 57.93 \\
\hline 5.5 & 2.281 & 31815 & 2281 & 2.69 & 7.16 & 13.64 & 47.47 \\
\hline 6.0 & 2.236 & 27145 & 2236 & 2.97 & 7.89 & 15.34 & 48.53 \\
\hline
\end{tabular}
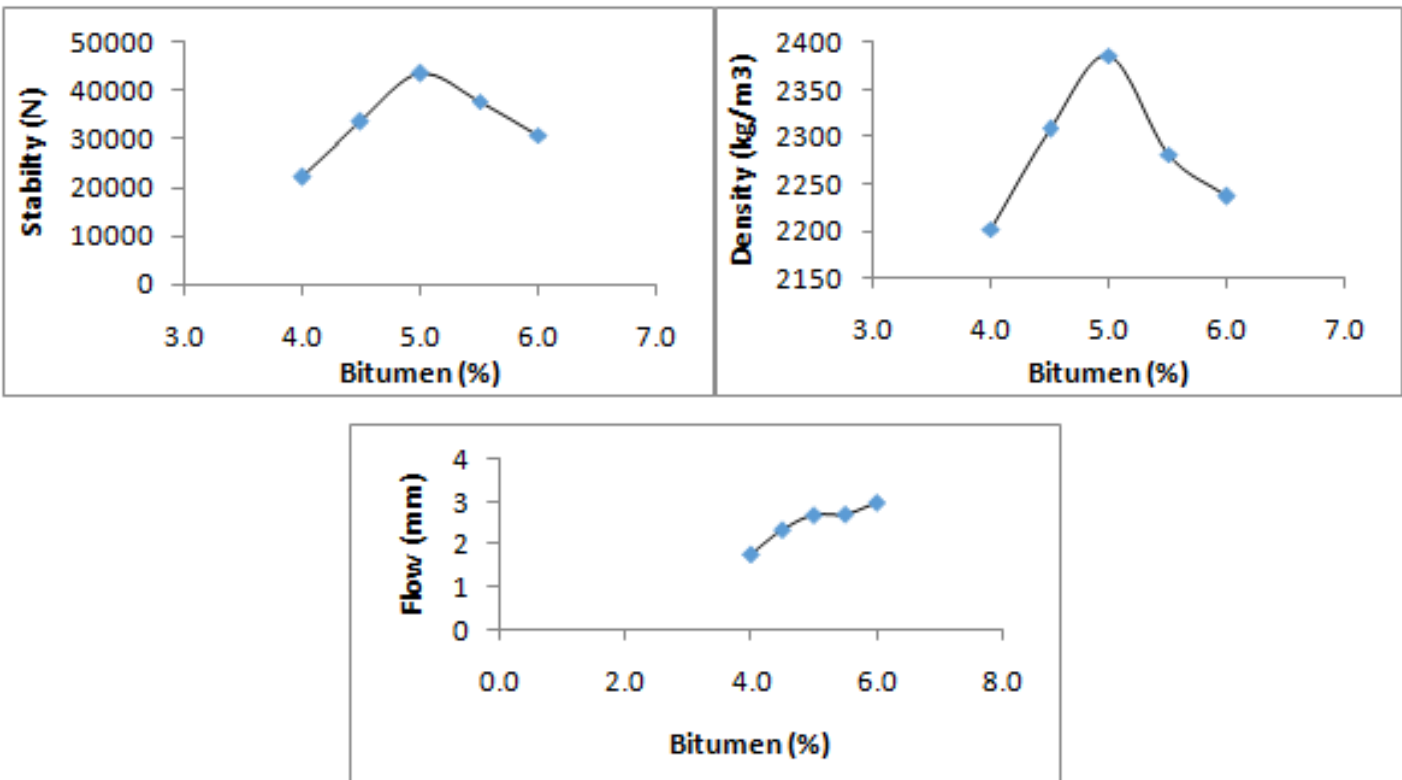
Laterite Rock Modified Asphalt Concrete Mix Design Properties and Swell Behaviour under Soaked Conditions for Rural Roads

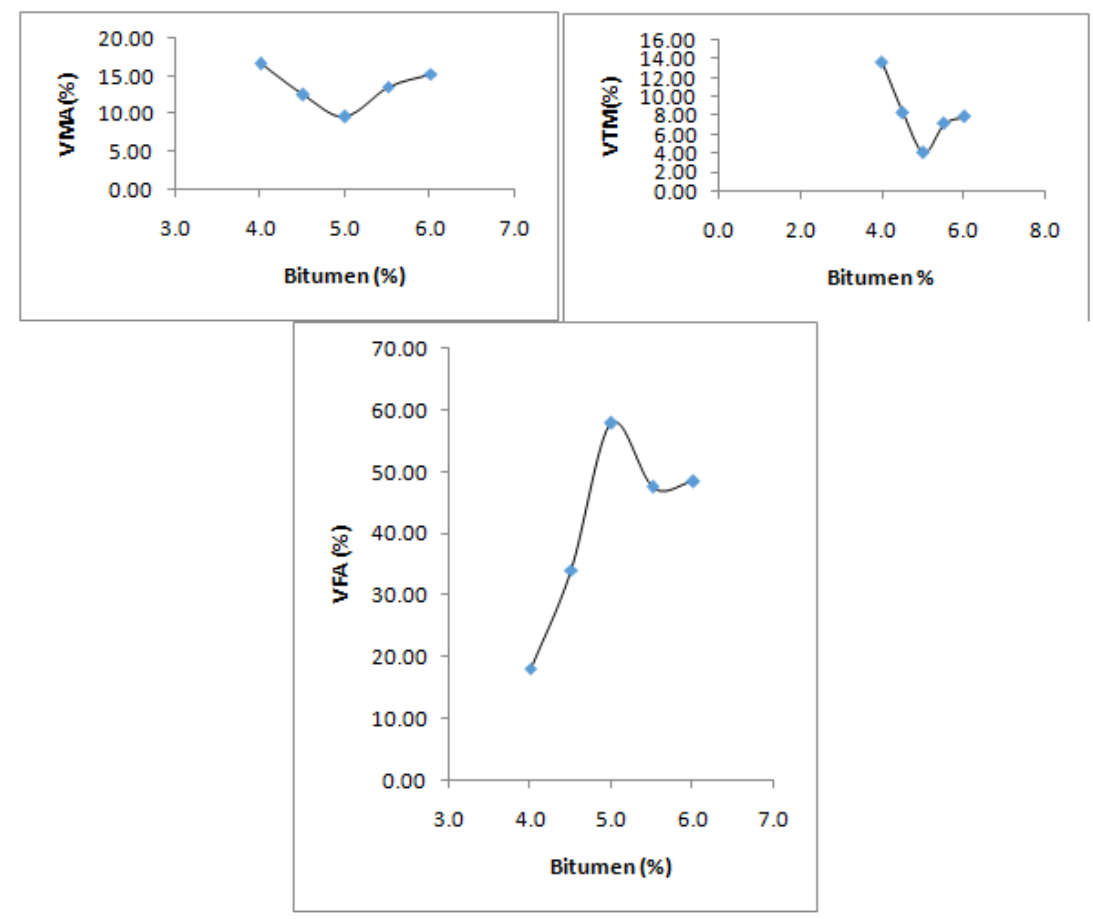

- Data for laterite rock concrete stabilized with Portland cement

\begin{tabular}{|c|c|c|c|c|c|c|c|c|}
\hline $0 \%$ & $\mathrm{Wa}$ & Ww & Swa & SWw & $\mathrm{Gmb}$ & $\mathrm{Va}$ & Vs & SI \\
\hline D0 & 1161.6 & 636.1 & 0.0 & & 2.211 & & & \\
\hline D1 & 1166.8 & 634.3 & 1176.1 & 655.0 & 2.191 & 2.557 & 2.654 & 3.8 \\
\hline D2 & 1167.7 & 630.4 & 1184.2 & 653.6 & 2.173 & 2.538 & 2.643 & 4.1 \\
\hline D3 & 1173.7 & 627.8 & 1192.4 & 652.9 & 2.150 & 2.523 & 2.636 & 4.4 \\
\hline D4 & 1176.8 & 624.9 & 1197.4 & 651.7 & 2.132 & 2.509 & 2.628 & 4.7 \\
\hline D5 & 1177.3 & 621.3 & 1203.5 & 648.8 & 2.118 & 2.493 & 2.611 & 4.7 \\
\hline \multicolumn{9}{|l|}{$2 \%$} \\
\hline D0 & 1153.9 & 635.7 & 0.0 & 0.0 & 2.227 & & & \\
\hline D1 & 1158.5 & 634.0 & 1172.0 & 653.6 & 2.209 & 2.559 & 2.650 & 3.6 \\
\hline D2 & 1164.6 & 632.1 & 1180.2 & 653.9 & 2.187 & 2.547 & 2.647 & 3.9 \\
\hline D3 & 1171.7 & 633.1 & 1189.3 & 655.8 & 2.175 & 2.549 & 2.651 & 4.0 \\
\hline D4 & 1174.7 & 631.8 & 1194.4 & 655.3 & 2.164 & 2.542 & 2.646 & 4.1 \\
\hline D5 & 1179.8 & 628.3 & 1201.5 & 654.8 & 2.139 & 2.524 & 2.641 & 4.6 \\
\hline \multicolumn{9}{|l|}{$4.0 \%$} \\
\hline D0 & 1155.8 & 642.1 & 0.0 & 0.0 & 2.250 & & & \\
\hline D1 & 1156.3 & 637.6 & 1169.0 & 655.6 & 2.229 & 2.578 & 2.662 & 3.3 \\
\hline D2 & 1156.5 & 632.4 & 1177.1 & 652.1 & 2.207 & 2.552 & 2.639 & 3.4 \\
\hline D3 & 1162.6 & 633.6 & 1185.2 & 655.0 & 2.198 & 2.555 & 2.649 & 3.7 \\
\hline D4 & 1168.7 & 633.6 & 1191.3 & 656.0 & 2.184 & 2.553 & 2.651 & 3.9 \\
\hline D5 & 1172.7 & 631.9 & 1198.4 & 656.7 & 2.168 & 2.543 & 2.651 & 4.2 \\
\hline $6.0 \%$ & 0.0 & 0.0 & 0.0 & 0.0 & & & & \\
\hline D0 & 1151.7 & 643.1 & 0.0 & 0.0 & 2.265 & & & \\
\hline D1 & 1153.4 & 641.2 & 1167.0 & 657.0 & 2.252 & 2.597 & 2.670 & 2.8 \\
\hline D2 & 1157.5 & 640.5 & 1174.1 & 658.0 & 2.239 & 2.592 & 2.671 & 3.1 \\
\hline D3 & 1160.6 & 638.3 & 1181.2 & 658.2 & 2.222 & 2.579 & 2.668 & 3.4 \\
\hline D4 & 1165.6 & 636.0 & 1186.3 & 657.3 & 2.201 & 2.565 & 2.660 & 3.7 \\
\hline D5 & 1168.7 & 633.8 & 1190.3 & 657.3 & 2.185 & 2.554 & 2.658 & 4.1 \\
\hline $8.0 \%$ & 0.0 & 0.0 & 0.0 & 0.0 & & & & \\
\hline D0 & 1155.1 & 649.6 & 0.0 & 0.0 & 2.285 & & & \\
\hline D1 & 1155.8 & 646.9 & 1165.9 & 661.3 & 2.271 & 2.625 & 2.694 & 2.6 \\
\hline
\end{tabular}


Laterite Rock Modified Asphalt Concrete Mix Design Properties and Swell Behaviour under Soaked Conditions for Rural Roads

\begin{tabular}{|c|c|c|c|c|c|c|c|c|}
\hline D2 & 1156.4 & 642.6 & 1179.1 & 659.8 & 2.251 & 2.603 & 2.677 & 2.9 \\
\hline D3 & 1158.5 & 641.3 & 1184.2 & 660.0 & 2.240 & 2.595 & 2.675 & 3.1 \\
\hline D4 & 1162.6 & 638.8 & 1184.2 & 658.6 & 2.219 & 2.580 & 2.668 & 3.4 \\
\hline D5 & 1165.6 & 636.5 & 1189.3 & 658.0 & 2.203 & 2.568 & 2.662 & 3.7 \\
\hline 10.0\% & 0.0 & 0.0 & 0.0 & 0.0 & & & & \\
\hline D0 & 1154.0 & 653.5 & 0.0 & 0.0 & 2.306 & & & \\
\hline D1 & 1155.4 & 649.8 & 1164.2 & 662.2 & 2.285 & 2.640 & 2.700 & 2.3 \\
\hline D2 & 1156.9 & 646.0 & 1206.5 & 664.1 & 2.264 & 2.620 & 2.684 & 2.5 \\
\hline D3 & 1158.0 & 642.4 & 1205.5 & 661.8 & 2.246 & 2.601 & 2.673 & 2.8 \\
\hline D4 & 1159.1 & 639.8 & 1192.5 & 659.7 & 2.232 & 2.587 & 2.669 & 3.2 \\
\hline D5 & 1166.1 & 639.5 & 1200.0 & 660.8 & 2.215 & 2.582 & 2.671 & 3.4 \\
\hline
\end{tabular}
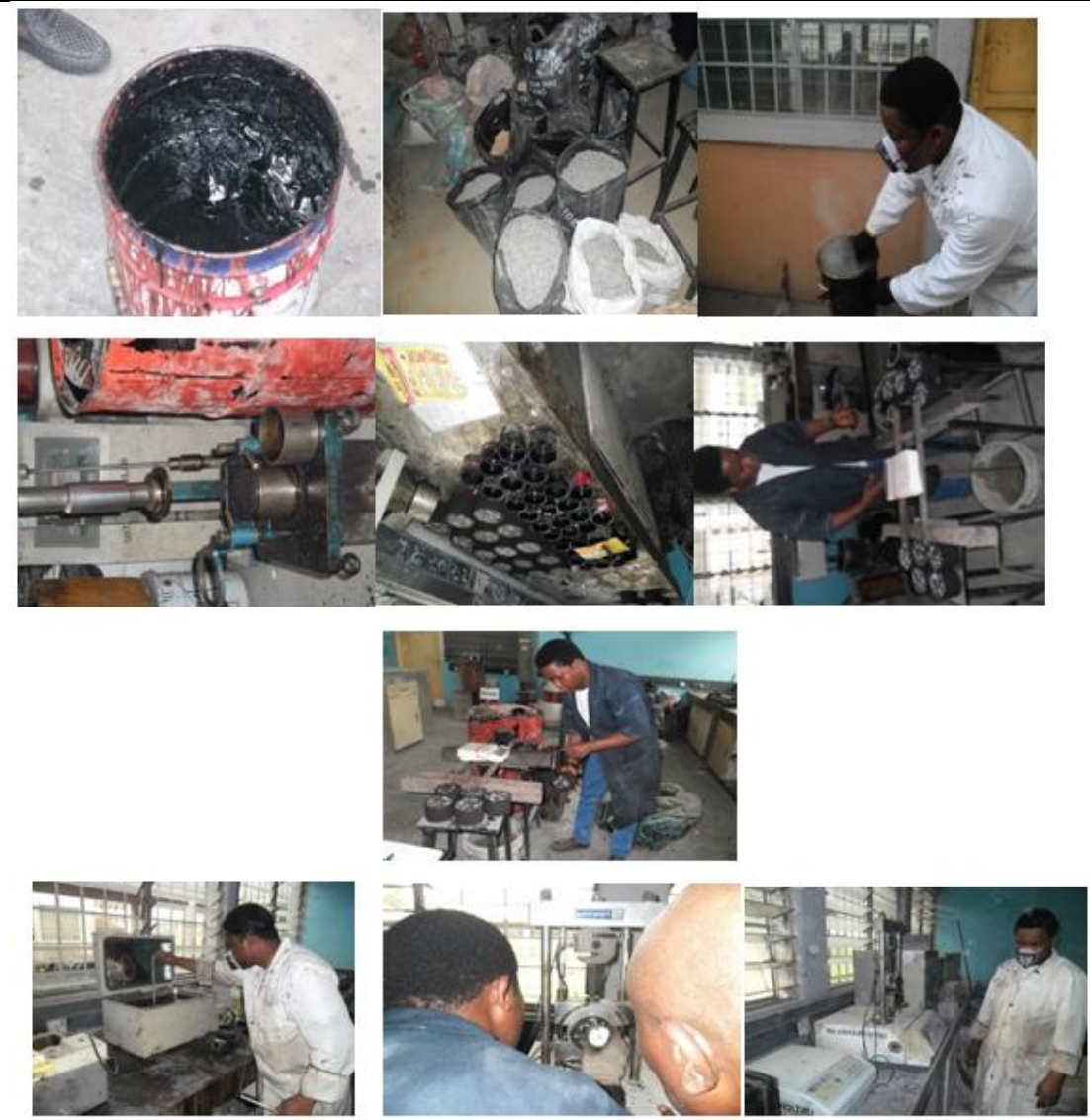

Plates

Citation: Nyebuchi, Daniel Azeruibe, et.al, "Laterite Rock Modified Asphalt Concrete Mix Design Properties and Swell Behaviour under Soaked Conditions for Rural Roads", International Journal of Constructive Research in Civil Engineering, 6(2), pp. 11-25. DOI: http://dx. doi.org/10.20431/24548693.0602002.

Copyright: () 2020 Authors, This is an open-access article distributed under the terms of the Creative Commons Attribution License, which permits unrestricted use, distribution, and reproduction in any medium, provided the original author and source are credited. 